\title{
CESTA ČESKÝCH MUZEJNÍCH INSTITUCÍ KE VZNIKU SVAZU ČESKOSLOVENSKÝCH MUSEÍ
}

FRANTIŠEK ŠEBEK

\section{ABSTRAKT/ABSTRACT:}

Studie se zabývá vznikem Svazu československých muzeí $\mathrm{v}$ roce 1919. Myšlenka na vznik profesního sdružení muzeí v českých zemích rezonovala na sjezdech muzejních spolků a ochránců památek od roku 1898. Postupně krystalizovalo několik návrhů na podobu sdružení, přičemž docházelo k názorovým střetům (1908 a dále). Krátce po vzniku Československa zvítězila myšlenka na vznik Svazu podle představ mladší generace pracovníků muzeí a s podporou Ministerstva školství a národní osvěty. Roku 1919 ve skutečnosti vznikl jenom Svaz československých muzeí vlastivědných. Studie se snaží odpovědět na otázku, proč tomu tak bylo a které konkrétní okolnosti vedly k založení Svazu, který se posléze otevřel i ostatním českým muzeím (1925).

\section{Czech museum institutions on the way to establishment of the Association of Czechoslovak Museums}

The study is dealing with establishment of the Association of Czechoslovak Museums in 1919. The idea of creating a professional association of museums in the Czech lands resonated in meetings of museum societies and monument conservators since 1898. The gradual crystallisation of several proposals for the form of the association was accompanied by a clash of opinions
(1908 and further). The winner was announced shortly after the emergence of Czechoslovakia - it was a concept of the Association developed by young generation of museum workers, who gained support from the Ministry of Public Instruction. In 1919, in fact only the Association of Czechoslovak National History Museums emerged. The study is searching for the reasons of this step and tries to elucidate the situation leading to establishment of the Association, which was later also open towards other Czech museums (1925).

\section{KLÍČOVÁ SLOVA/KEYWORDS:}

muzea - Svaz československých muzeí - vlastivědná muzea - sít muzeí v českých zemích - historie muzeí $v$ českých zemích museums - Association of Czechoslovak Museums - national history museums - museum network in the Czech lands - museum history in the Czech lands

Svaz československých museí, založený roku 1919, byl prvním českým profesním sdružením v oboru muzejnictví v českých zemích, které nezanedbatelným způsobem ovlivňovalo vývoj našeho muzejnictví po dobu čtyř desetiletí, než nepřízeň doby (nástup totalitního komunistického režimu) přivodila na sklonku padesátých let 20. století jeho zánik. Předpokladům a samotnému vzniku Svazu československých museí (dále jen Svaz) se před padesáti lety podrobně věnoval již
Jiří Špét. ${ }^{1}$ Přesto je snad namístě u př́ležitosti stoletého jubilea vzniku tohoto muzejního sdružení připomenout okolnosti jeho vzniku a upozornit na některé dosud málo zdůrazňované aspekty.

Hned úvodem nutno poznamenat, že Svaz nebyl jediným profesním sdružením muzeí v Československu, nýbrž že vedle něj existoval od roku 1922 také Verband der Deutschen Museen für Heimatkunde in der Tschechoslowakischen Republik. Ten postupně sdružoval přibližně 20 až $30 \%$ ze všech muzeí v českých zemích. ${ }^{2}$ Vedle

1 ŠPÉT, Jiří. Vznik Svazu československých muzeí. Muzejní a vlastivědná práce, 1971, roč. 9, č. 2, s. 90-109. Závěry této studie uplatnil její autor v souhrnné práci ŠPÉT, Jiří. Přehled vývoje českého muzejnictví I. (do roku 1945). 2. vyd. Brno: Masarykova univerzita v Brně, 2003, s. 72 a dále. Podobně ŠPÉT, Jiří. Muzea ve vývoji společnosti a národní kultury. Praha: Národní muzeum, 1979, s. 128-132. Některé aspekty vzniku a působení Svazu nedávno připomenul ŠEBEK, František. Role Svazu československých muzeí ve vývoji českého (československého) muzejnictví. In HUPKO, Daniel a Luděk BENEŠ (eds.). Dokumentácia „osmičkových" výročí v slovenských a českých múzeách. Rok 1918 a tie ostatné. Banská Bystrica: Zväz múzeí na Slovensku, 2018, s. 128-142.

2 K roku 1931 se uvádí, že Verband sdružoval 59 muzeí (viz Časopis pro dějiny venkova, 1932 roč. 14, s. 225) a k roku 1937 již 91 německých muzeí (viz ŠPÉT, Jiří. Přehled vývoje českého muzejnictví I. (do roku 1945). 2. vyd. Brno: Masarykova univerzita v Brně, 2003, s. 97). Celkový počet muzeí v českých zemích se během první republiky pohyboval mezi 250 (údaj k roku 1923) až 360 muzei (k roku 1937). K celkovému počtu muzeí u nás naposledy viz ŠEBEK, František. Sít a struktura muzeí. In ŠEBEK, František a kol. (eds.). Muzea ČR $v$ letech 2012-2014 ve světle statistiky. Praha: NIPOS, 2015, s. 11-12. Též ŠEBEK, František. Stav muzejnictví z pohledu statistických dat. In BENČOVÁ, Monika a Anna KOMÁRKOVÁ (eds.). Muzeum a změna V./The Museum and Change V.: Sborník z mezinárodní muzeologické konference v Národním archivu v Praze 22.-24. listopadu 2016. Praha: Asociace muzeí a galerií České republiky, 2017, s. 135-137. 
toho ještě uved'me, že od roku 1939 se s rozpadem státu oddělila od Svazu slovenská muzea, založila Zväz slovenských muzeí, ${ }^{3}$ a zbylý Svaz československých museí se přejmenoval na Svaz českých museí. ${ }^{4} \mathrm{~K}$ obnovení jednotného Svazu už nedošlo ani po druhé světové válce.

Zakládající sjezd Svazu se konal v Praze 27. a 28. září (tedy na sv. Václava) roku 1919. Účastnilo se jej něco přes 60 osob, tj. delegovaní zástupci 56 muzeí z českých zemí a několik zástupců ze Slovenska. ${ }^{5}$ Všimněme si tu několika charakteristických skutečností tohoto sjezdu. Zaujmout nás může poměrně malý počet přítomných muzeí. V českých zemích tehdy (přesněji, k roku 1923) existovalo zhruba 182 českých vlastivědných muzeí (128 v Čechách, 40 na Moravě a 14 ve Slezsku). Sjezdu se tedy účastnila sotva třetina dotčených subjektů. ${ }^{6}$ Neúčastnila

3 Stanovy Zväzu slovenských muzeí byly schváleny koncem roku 1939, činnost Zväz zahájil od roku 1940. Viz k tomu přehledně naposledy PALÁRIK, Miroslav. Museums in the Slovak Republic (1939-1945) - origins, visions and reality. Museologica Brunensia, 2017, roč. 6, č. 2, s. 46-55. Zde též odkazy na další literaturu k tématu.

4 Miroslav Palárik ve studii citované zde v pozn. 3. hovoří k roku 1938, respektive 1939 o zániku Svazu československých muzeí, což není po mém soudu přesné.

5 Podrobnou zprávu o sjezdu zveřejnil zejména Časopis společnosti prátel starožitností, 1919, roč. 27, s. 69-71. Poté ještě HARLAS František Xaver. Svaz československých museí vlastivědných. Časopis Společnosti přátel starožitností českých, 1920, č. 1, roč. 28, s. 46-49. Přehled účastníků sjezdu uvádí ŠPÉT, Jiří. Přehled vývoje českého muzejnictví I. (do roku 1945). 2. vyd. Brno: Masarykova univerzita v Brně, 2003, s. 74 , pozn. 8

6 Vycházím z údajů o počtu muzeí jednotlivých typů k roku 1923, které uvádí ŽALUD, Augustin. Česká kulturní politika a musea. In TOBOLKA, Zdeněk (ed.). Politika. Co má věděti o Československé republice každý občan. Praha, 1925, díl II/3, s. 188-189. Žalud se odvolává na zdroje Svazu. Při procentním výpočtu účasti muzeí na sjezdu jsem z 56 účastníků odečetl 4 muzea, která Žalud nezahrnoval ve své statistice mezi „vlastivědná“ muzea. K této problematice jen ještě pro ilustraci uved'me, že druhý sjezd českých archeologů a spolků musejních roku 1898 v Kutné Hoře měl něco kolem 200 účastníků (muzeí bylo tehdy méně než roku 1919) a následující Sjezd na ochranu památek roku 1908 v Praze měl přes 200 účastníků. Viz Časopis společnosti prátel se ani slovenská muzea, ale jenom zástupci slovenské muzejní reprezentace (zástupce komisariátu pro památky z Bratislavy, jenž měl v gesci oblast muzejnictví na Slovensku; konzervátor bratislavské župy; zástupce Svazu pro okrašlování a ochranu domoviny). Ministerstvo školství a národní osvěty (MŠANO), jež stálo u zrodu této iniciativy, přitom muzeím rozeslalo informaci o chystaném založení Svazu spolu s návrhem stanov a výzvou k zaslání připomínek již v květnu 1919.7 MŠANO nemělo sebemenší důvod tuto akci na Slovensku tajit; evidentně ji znal bratislavský komisariát pro památky. Tato záležitost patrně ještě stojí za hlubší prozkoumání.

S otázkou relativně nízké účasti muzeí na zakládajícím sjezdu souvisí jistě i skutečnost, že prvotním záměrem zakladatelů bylo ustavit toliko svaz muzeí vlastivědných. Tak také sjezd nakonec schválil jeho název: Svaz československých museí vlastivědných. Specializovaná muzea ostatně na sjezd pozvánku ani nedostala. Vyloučení specializovaných muzeí provedené zakladateli Svazu se setkala s kritikou delegátů nejenom na sjezdu, ale už i v připomínkovém řízení k návrhu stanov. ${ }^{8}$ Výslovné zmínky o omezení činnosti Svazu jenom na vlastivědná muzea nakonec schválené znění stanov vypustilo, ale název a z něho logicky vyplývající redukce členství zůstala. Ustoupilo se od ní až s první dílčí změnou stanov i názvu sdružení v roce 1925. Důvody,

starožitností českých, 1898, roč. 6, s. 110; 1908, roč. 16, s. 211.

7 Toto tvrzení opírám o dopis vedoucího oddělení památek a muzeí MŠANO Dr. Zdeňka Wirtha z konce srpna 1919 adresovaný Musejnímu spolku v Pardubicích, v němž urguje zaslání eventuálních připomínek k návrhu stanov Svazu, který spolek obdržel (viz Státní okresní archiv Pardubice, fond Musejní spolek Pardubice, kart. 4, sign. 4/104).

8 Viz např. dokument citovaný v předchozí poznámce. jež vedly zakladatele Svazu k oné redukci členství, z dostupných dokumentů přímo nepoznáme. Zatím se tedy musíme spokojit jenom s domněnkami. Ještě se k tomu vrátíme. Zatím jen dodejme, že opatrný odstup některých muzeí od záměru vytvoření Svazu, jak jej představoval předložený návrh stanov, byl patrně hlubší než jenom zmíněná redukce členství. Je to vidět i z toho, že po zakládajícím sjezdu se do Svazu přihlásilo jenom 46 muzeí z 56 jeho účastníků. Do roku 1923 se sice počet členů zdvojnásobil na 97, ale to představovalo sotva $50 \%$ z celkového počtu existujících vlastivědných muzeí. ${ }^{9}$ Teprve později, když se praktickými kroky Svazu ukazovala jeho prospěšnost a Svaz se otevřel i muzeím specializovaným, zájem o něj výrazně stoupal. K roku 1937 se ke Svazu už hlásilo téměř 90 \% všech českých a slovenských muzeí. ${ }^{10}$

V souvislosti se založením Svazu v září 1919 stojí také za povšimnutí, že se ustavil záhy po vzniku Československa. Bylo to v době,

9 Počet členů Svazu uvedený v jednatelské zprávě Karla Gutha přednesené na sjezdu Svazu roku 1923 cituji podle ŠPÉT, Jiří. Přehled vývoje českého muzejnictví I. (do roku 1945). 2. vyd. Brno: Masarykova univerzita v Brně, 2003, s. 81. Špét však uvádí mylně k datu 1923 počet všech vlastivědných muzeí (128). Jednalo se jenom o venkovská vlastivědná muzea v Čechách. Českých venkovských vlastivědných muzeí v Čechách, na Moravě a ve Slezsku bylo k roku 1923 ve skutečnosti 182 . K tomu nutno připočítat několik ústředních muzeí (též členů Svazu) a muzea na Slovensku (české zdroje hovoří k tomuto datu o 22 muzeích, ne však $\mathrm{z}$ toho o počtu těch vlastivědných, respektive nespecializovaných). Ve výše uvedeném výpočtu jsem tedy vycházel z celkového čísla 195 vlastivědných muzeí Podrobně rozvádí strukturu a počet muzeí v Československu v této době ŽALUD, Augustin. Česká kulturní politika a musea. In TOBOLKA, Zdeněk (ed.). Politika. Co má věděti o Československé republice každý občan. Praha, 1925, díl II/3, s. 188-189.

10 K roku 1931 uvádí jednatelská zpráva Svazu 170 členů a o rok později176. (Viz Časopis pro dějiny venkova, 1931, roč. 18, s. 271; 1932 , roč. 19, s. 140). K roku 1937 to již bylo 247 členů Svazu (cituji podle ŠPÉT, Jiří. Přehled vývoje českého muzejnictví I. (do roku 1945). 2. vyd. Brno: Masarykova univerzita v Brně, 2003, s. 82.) Všech muzeí bylo až 360 (viz literatura v pozn. 2). Z toho bylo 91 německých. Českých a slovenských tedy zhruba 269. 
kdy republika teprve usilovala o mezinárodní uznání svého teritoria, s čímž souvisela nutnost vojenských zásahů v oblastech s německým obyvatelstvem i otevřené střety s Mad’arskem a Polskem. Obyvatelstvo trpělo hladem, chyběly suroviny pro průmysl, rozvrácené zůstaly obchodní vazby mnohých firem i celých odvětví se zeměmi bývalé monarchie. Trvalo nějaký čas, zhruba do poloviny dvacátých let, než se situace postupně stabilizovala a země se nadechla k rozvoji. Jestliže se tedy profesní sdružení muzeí (byt' jenom jejich nejpočetnější skupiny) zrodilo už 11 měsíců po revolučním 28. říjnu 1918, stalo se tak proto, že se jednalo o logické vyústění předchozího vývoje muzejní komunity už před první světovou válkou i během ní.

\section{V českých zemích od} sedmdesátých let a potom zvláště od osmdesátých let 19. století rostl energicky počet muzeí. Jestliže k roku 1870 tu existovalo 10 muzeí, v roce 1880 třikrát tolik a k roku 1890 už 68. Na samém začátku 20. století jejich počet vzrostl na 150. Růst počtu muzeí se ani potom nezastavil. ${ }^{11}$ Dominantním typem se stala muzea vlastivědná - městská i místní, okresní, krajinská (krajová). Z celkového počtu 150 muzeí na začátku 20. století jich bylo 113 . Zakládána byla také specializovaná muzea umělecko-průmyslová, respektive umělecko-řemeslná, která ve zmiňovaném období prodělala poměrně složitý vývoj. Ojediněle i s jinou specializací. Naznačená exploze zakládání muzeí měla kořeny $\mathrm{v}$ hlubších společenských proměnách, které na tomto místě nemůžeme podrobněji sledovat. Jako jeden z významných katalyzátorů toho působilo v letech

11 Ke zde uváděným údajům o vývoji počtu muzeí viz doklady uvedené v literatuře citované v pozn. 2 .
1891-1895 tzv. národopisné hnutí, spjaté s přípravami a průběhem Národopisné výstavy českoslovanské v Praze (1895). Je přirozené, že v době oné vlny někdy až živelného zakládání muzeí pocitovala řada představitelů muzejní komunity nebo osobností z univerzitního prostředí potřebu vzájemné komunikace a hlubšího zamýšlení nad podstatou ochrany i uchování památek a obecně muzejních aktivit. A tak se $\mathrm{v}$ roce 1893 sešel první sjezd muzejních a archeologických spolků v Hlinsku, o pět let později druhý v Kutné Hoře (1898) a na něj potom navázaly ještě do první světové války dva pražské sjezdy na ochranu památek (1908 a 1913).

Ještě předtím, než se sešel první sjezd v Hlinsku, otiskl roku 1892 Lubomír Niederle, tehdy mladý ambiciózní vědec, $\mathrm{v}$ prvním ročníku jím spolu s Čeňkem Zíbrtem právě založeného časopisu Český lid článek Několik slov o pěstování české archeologie. ${ }^{12}$ Niederle měl za sebou studijní pobyty v Německu a Francii a studijní cesty po řadě evropských muzeí, zvláště archeologických. $\mathrm{V}$ podnětné studii, která se týkala řady aspektů archeologické práce v Čechách (srovnával ji s praxí v jiných zemích), si všímal i stavu pramenné základny, úrovně terénní práce, dokumentace nálezů a dostupnosti archeologických sbírek v muzeích. Kriticky se vyjádřil k Národnímu muzeu a logicky se dotkl také stavu početných a stále přibývajících regionálních muzeí. Niederle dospěl k závěru, „že krajinská archeologická musea jsou na újmu povznesení vědecké práce $v$ Čechách, že centralisace sbírek v Praze byla by prospěšnější." ${ }^{13}$ Byl si vědom nereálnosti své

12 NIEDERLE, Lubomír. Několik slov o pěstování české archeologie. Český lid, 1892, roč. 1, s. 317-331.

13 Tamtéž, s. 328. představy a korektně zvažoval výhody i nevýhody krajinských a místních muzeí. Když nejde zavézt centralismus v ukládání sbírek, zdůrazňoval potřebu stálých kvalifikovaných zaměstnanců $\mathrm{v}$ těchto muzeích, žel rovněž nereálnou.

Aniž by Niederle v komentovaném článku vztah Národního a venkovských muzeí vymezoval nějak kategorický (později mu to občas někteří přisuzovali), vyvolal odmítavou reakci zastánců krajinských a místních muzeí. Ještě v roce 1892 se na dané téma ozval nejprve hlinecký Karel Václav Adámek v článku O museích krajinských a o statistice musejní vyšlém v Rozpravách Společnosti přátel starožitností českých. ${ }^{14}$ Postupně se přidávali další (čáslavský K. Čermák a V. V. Jeníček), ${ }^{15}$ zdůrazňující podobně jako Adámek nezastupitelnou roli regionálních muzeí. Tato otázka rezonovala na výše zmíněných muzejních sjezdech. Nedalo se ale v žádném případě pominout problémy s nestabilitou mnoha venkovských muzeí, které vesměs zřizovaly nebo spravovaly spolky dobrovolníků a jejichž existence spočívala toliko na individuální iniciativě jednotlivců, často nadšených a obětavých.

\footnotetext{
14 ADÁMEK, Karel Václav. O museích krajinských a o statistice musejní. Rozpravy Společnosti přátel starožitností českých, 1892, roč. 3, s. 77-83.

15 Viz např́klad referáty a vystoupení zmíněných autorů na sjezdu muzejních spolků v roce 1898 a 1908: Sjezd českých archeologů a spolků musejních konaný 27. a 28. srpna 1898 na Horách Kutných. Praha: Společnost přátel starožitností českých, 1898, s. 26-27; Sjezd na ochranu památek. Českoslovanské letopisy musejní, 1910, roč. 2. Viz též ČERMÁK, Kliment. O radě musejní. Časopis Společnosti prátel starožitností českých, 1898, roč. 6, č. 3, s. 131-133; JENÍČEK, Václav Vladislav. O organisaci musejních spolků českoslovanských. Časopis Společnosti přátel starožitností českých, 1898, roč. 6, č. 3, s. 133-134. Viz též rozsáhlý výklad shrnující též závěry tř́ muzejní sjezdů $(1893,1898,1908)$ a historii českého muzejnictví, který podal ADÁMEK, Karel Václav. Musea v Království českém. Česká revue, 1908-1909, roč. 2, č. 4, s. 232-244, 282-300.
} 
Tato muzea měla většinou velké potíže s prostorovým vybavením a finančním zajištěním. Nové účelové muzejní budovy stavěné na konci 19. a začátku 20. století ve větších městech (s několika staršími jich do první světové války v českých zemích vzniklo 14$)^{16}$ byly v podstatě jenom kapky v moři. Nedala se pominout ani živelnost ve vznikání některých muzeí bez kvalifikovaného vymezení územní působnosti (leckdy se překrývající s jiným muzeem) a bez smysluplně vybraného zaměření činnosti. Motivem založení takových muzeí bývala módní vlna společenskopolitických aktivit a někdy i otázka zvýšení prestiže reprezentace města.

Jen zvolna se prosazovalo moderní muzeologické pojetí práce a stále ještě se v praxi považovalo za jediný cíl ochotnické sběratelství. Vědecká hlediska se brala v potaz jen zřídka. Ostatně odborně zdatní pracovníci byli vzácností. Národní muzeum se uzavíralo do sebe a mezi ním a venkovskými muzei existoval (až na čestné výjimky) hluboký příkop.

\section{Řešení nastíněných problémů} hledali zastánci vlastivědných muzeí v návrzích na legislativní opatření, která by zaručila minimální finanční zajištění muzeí, ve vytvoření sdružení s povinným členstvím všech muzeí Království českého. To by garantovalo sít muzeí se striktně vymezeným územním působením jednotlivých subjektů, včetně oktrojované struktury muzeí jednotlivých typů, zavedení jednotných stanov apod. Takové návrhy měly postupně několik variant a také malou šanci na reálné prosazení.

16 Souhrnný přehled těchto staveb viz ŠEBEK, František. Architektura muzejních budov, funkční členění a vybavení prostor. In BURIÁNKOVÁ, Michaela, Anna KOMÁRKOVÁ a František ŠEBEK (eds.). Úvod do muzejní praxe. Praha: Asociace muzeí a galerií České republiky, 2010, s. 371-374.
Na pražském sjezdu na ochranu památek v roce 1908 se proti takovým návrhům ohradil Albín Stocký, mladý archeolog Národního muzea. Ten naopak doporučoval ustavení svazu muzeí s dobrovolným členstvím, který by zaručoval jejich individualitu. Stocký nesouhlasil s omezováním zakládání místních muzeí, čímž se vymezil i proti předem dané a petrifikované síti. Proti tomu zdůrazňoval potřebu vnitřní obrody práce muzeí při prosazení odborného vedení a prohloubení profesionality. Do muzeí měla více proniknout věda, moderní prostředky a metody práce. Tyto trendy měl prosazovat, respektive všemožně podporovat navrhovaný svaz. $^{17}$

Vystoupení Stockého vyvolalo nevraživý odpor „zasloužilých“ koryfejů české muzejní komunity (zvláště K. V. Adámka) a také rozpačitou nedůvěřivost řady praktiků: pochybovačů, že by do takového svazu nevstoupilo Národní muzeum a ostatní ústřední instituce, že venkovská muzea nebudou mít šanci získat odborníky a uskutečnit onu obrodu. V této souvislosti stojí za zaznamenání, že Stockého vystoupení nakonec ani nebylo otištěno ve sborníku sjezdových referátů s odůvodněním, že autor dodal redakci sborníku text pozdě. Stocký to veřejně odmítl a své názory aspoň ve výtahu publikoval na stránkách Časopisu Společnosti přítel starožitností českých v roce $1910 .{ }^{18}$

\footnotetext{
17 STOCKÝ, Albín. Svaz museí a musejních spolků. Časopis společnosti prátel starožitností českých, 1910, roč. 18, č. 2, s. 56-59.

18 Viz práce citovaná výše v pozn. 17 a k tomu dále STOCKÝ, Albín. K článku o Svazu musejí. Časopis společnosti přátel starožitností českých, 1910, roč. 18, č. 2, s. 60; PAKOSTA, Ferdinand. Dodatek k článku o Svazu musejí. Tamtéž, č. 2, s. 60. Rezolutní odmítnutí Stockého názorů viz např. ADÁMEK, Karel Václav. Musea v Království českém. Česká revue, 1908-1909, roč. 2, č. 4, s. 282-300. Ve sborníku ze sjezdu z roku 1908 nebyl otištěn ani diskusní příspěvek plzeňského Fridolína Macháčka.
}

Názory Albína Stockého nicméně našly pozitivní ohlas na půdě Národního muzea u tam nastupující mladé generace pracovníků, která hodlala prosadit výraznou reformu struktury i programu činnosti Národního muzea. ${ }^{19}$ Patřil k nim zvláště historik umění a archeolog Karel Guth. V roce 1913, kdy se v Praze konal čtvrtý sjezd muzeí (druhý na ochranu památek), se konala také přátelská schůze zájemců o uvažované organizaci našich muzeí. Guth tehdy podpořil myšlenku jednotné organizace muzeí zemí českoslovanských na stránkách Národních listů. Jednotu by mělo podle něj iniciovat především Národní muzeum, což by bylo „nejkrásnější oslavou jeho příštího stoletého jubilea“ (1918). ${ }^{20}$ S názorem na potřebu sdružení muzeí a očekávaným zapojením Národního muzea, které by přispělo k obrodě venkovských vlastivědných muzeí, se připojovali další: plzeňský ředitel městského archivu a historického muzea Fridolín Macháček, organizátor zemědělského muzejnictví Josef Kazimour aj.

Přišel rok 1918, rozpad monarchie a vznik republiky. Od poloviny listopadu 1918 přešlo muzejnictví pod gesci Ministerstva školství a národní osvěty, konkrétně 25. oddělení VII. odboru národní osvěty, které řídil Zdeněk Wirth, historik dějin architektury a aktivní účastník muzejních sjezdů 1908 a 1913 v Praze. Ministerstvo vytvořilo při oddělení expertní

19 Přehledně o změnách v Národním muzeu a úvahách o vzniku svazu muzeí na půdě této instituce viz SKLENÁř, Karel. Obraz vlasti. Př́běh Národního muzea. Praha: Paseka, 2001, s. 315-320, 329.

20 Článek otištěný nejprve v Národních listech 10. V. 1913 na 1. straně jako fejeton pod šifrou G zveřejněn jako GUTH, Karel. K programu činnosti českých muzeí. Casopis společnosti prátel starožitností českých, 1913, roč. 21, č. 2, s. 93. Průběh sjezdu na ochranu památek v roce 1913 viz zejména Druhý sjezd na ochranu památek v Praze 1913 (IV. sjezd archeologů a spolků muzejních. Praha 1915 (68 stran). 
poradní sbor pro muzejnictví. ${ }^{21}$ Výrazné zastoupení v něm měli pracovníci Národního muzea z mladé „reformní“ skupiny (Guth a Stocký), Josef Kazimour a stoupenci myšlenky potřebných změn pojetí práce venkovských muzeí, jako byl již zmíněný Fridolín Macháček nebo Jaroslav Helfert z Brna. $\mathrm{V}$ diskusi se objevovala řada zásadních otázek organizačních i koncepčního charakteru, které si vyžadovaly ingerenci státu.

Aktuálně se objevila také otázka vytvoření mechanismu rozdělování finančních dotací muzeím z prostředků přidělených ministerstvu pro tento účel. Hrozilo, že by těmi, kdo budou posuzovat žádosti muzeí $\mathrm{z}$ různých koutů země o poskytnutí dotací na svou činnost, tedy nutně byrokraticky a logicky často nekompetentně a pod nejrůznějšími tlaky, měli být úředníci ministerstva (za asistence vyvolených členů poradního sboru).

Ze všech těchto důvodů vyvstala potřeba vytvořit na demokratických principech svaz muzeí, jako reprezentanta oboru v zemi. Za myšlenku, kterou prý (!) poprvé na půdě poradního sboru vyslovil Josef Kazimour, ${ }^{22}$ se postavilo ministerstvo, konkrétně Zdeněk Wirth. Záhy se tedy začalo připravovat ustavení Svazu. Za hlavní konstruktéry tohoto projektu lze bezesporu považovat vedle zmíněného Wirtha především Karla Gutha a Fridolína Macháčka. Stojí za zmínku, že Guth, Macháček, Wirth spolu s dalšími (např. Václav Vojtíšek) byli vrstevníci, osobní prátelé již z dob studií na pražské filozofické fakultě, a kteří se také

\footnotetext{
21 Viz o tom blíže WIRTH, Zdeněk. Organizace ministerstva školství a národní osvěty Československé republiky. Umění, 1918, roč. 1, s. 246-249.

22 Uvedl to v nekrologu Josefa Kazimoura v roce 1933 Fridolín Macháček. Jiný doklad k tomu neexistuje. Viz MACHÁČEK, Fridolín. Kazimourův podíl na vývoji českého musejnictví. Časopis pro dějiny venkova, 1933, roč. 20, č. 3, s. 160.
}

přátelsky hlásili ke svému učiteli, profesoru Václavu Novotnému. ${ }^{23}$ Guth a Macháček také po celou dobu existence představovali klíčové osobnosti Svazu. Návrh stanov byl dílem Fridolína Macháčka. ${ }^{24}$

Jistá komplikace nastala, že při formování kompetencí správních struktur byla v roce 1919 vyjmuta $\mathrm{z}$ kompetence MŠANO všechna zemědělská muzea (spolu se zemědělským vzděláváním apod.), která měla být i finančně dotována ministerstvem zemědělství. To bylo do značné míry dílo Josefa Kazimoura, který v té době začal rozvíjet velkorysý projekt zemědělského muzejnictví rozprostřeného po celé republice ${ }^{25}$ a díky jeho mimořádným organizačním schopnostem a politickému angažmá se mu to vcelku dařilo, i když ne $\mathrm{v}$ jím uvažovaném rozsahu. To byl podle mého soudu hlavní důvod, proč zakladatelé Svazu jej proponovali bez specializovaných muzeí. Také umělecko-průmyslová muzea byla v naději, že budou finančně podporována ze zvláštních dotací ministerstva průmyslu a obchodu místo dřivějších podpor obchodních a živnostenských komor (ty prodělávaly reorganizaci). Nedošlo $\mathrm{k}$ tomu nakonec. Logicky se potom $\mathrm{v}$ roce 1925 otevřely brány Svazu i jim. Záležitosti ostatních

23 Viz k tomu BĚLOHLÁVEK, Miloslav. Fridolín Macháček a česká vlastivěda. Acta regionalia, 1966-1967, roč. 2, s. 48; JANEČKOVÁ, Jitka. Mráz kopřivu nespálí. Život a dílo Fridolína Macháčka a Václava Vojtíška ve vzájemné korespondenci z let 1905-1954. Praha: Scriptorium, 2014. O vztahu výše jmenovaných k prof. Václavu Novotnému viz též HOFFMANOVÁ, Jaroslava. Václav Novotný (1869-1932). Život a dílo univerzitního profesora českých dějin. Praha: Academia, 2014, s. 160, 168, 185-186.

24 Fridolína Macháčka označil za autora návrhu stanov Svazu Zdeněk Wirth v dopise pardubickému muzejnímu spolku uvedeném výše v pozn. 7.

25 Z četných prací Souhrnně o těchto aktivitách J. Kazimoura viz ŠTEFÁNEK, Antonín. PhDr. Josef Kazimour jako musejník. Časopis pro dějiny venkova, 1933, roč. 20, č. 3, s. 154-158; viz též odkaz na Wirthův článek v pozn. 12. specializovaných muzeí se zdály být v roce 1919 zřejmě marginální.

O tom, že přidělování finančních dotací z rozpočtu od MŠANO představovala pro ministerstvo choulostivou věc (a jeden $\mathrm{z}$ důvodů iniciování vzniku Svazu), svědčí fakt, že v prvních letech (do 1922) předkládalo ministerstvo Svazu (jeho muzejní radě) k posouzení žádosti všech muzeí, to je i nečlenských, včetně muzeí německých. Tím se také zrodila myšlenka vzniku německého Verbandu.

Svatováclavský zakládající sjezd Svazu roku 1919 schválil také organizační strukturu sdružení. Jak již bylo řečeno, členství institucí bylo dobrovolné. Členské příspěvky měly několik kategorií podle velikosti muzea. Každoročně se svolával sjezd (valná hromada) všech členů, což se ukázalo být důležitým nástrojem komunikace muzeí (výměna zkušeností, diskuse o aktuálních otázkách apod.). Sjezdy mívaly účast mezi třetinou až polovinou členů. Konávaly se na různých místech dva dny a vždy jednou za tři roky na Slovensku. Řídícím orgánem Svazu byla muzejní rada, která sestávala $\mathrm{z}$ voleného předsedy, 2 místopředsedů a 9 sjezdem volených členů. Jednoho dalšího člena muzejní rady jmenovalo MŠANO, jednoho Národní muzeum v Praze. Mezi místopředsedy byla pozice druhého místopředsedy vyhrazena pro zástupce slovenských muzeí. Celkem se tedy jednalo o sbor čtrnácti osob volených nebo jmenovaných na tři roky.

Muzejní obec během první republiky dokázala ze svých řad vygenerovat do čela Svazu řadu vynikajících osobností. Ti posouvali české muzejnictví, krůček po krůčku, někdy klopýtavě, ale vytrvale kupředu. Svaz jednoznačně prokázal své opodstatnění. Přes řadu vydaných studií si myslím, že 
všestranné zhodnocení působení Svazu v našem muzejnictví stále ještě čeká na své autory.

\section{POUŽITÉ PRAMENY A LITERATURA:}

Státní okresní archiv Pardubice, fond Musejní spolek Pardubice, kart. 4.

ADÁMEK, Karel Václav. Musea v Království českém. Česká revue, 1908-1909, roč. 2, č. 4, s. 232-244, 282-300.

ADÁMEK, Karel Václav. O museích krajinských a o statistice musejní. Rozpravy Společnosti přátel starožitností českých, 1892, roč. 3, s. 77-83.

BĚLOHLÁVEK, Miloslav. Fridolín Macháček a česká vlastivěda. Acta regionalia, 1966-1967, roč. 2, s. 48-65.

ČERMÁK, Kliment. O radě musejní. Časopis Společnosti přátel starožitností českých, 1898 , roč. 6, č. 3, s. 131-133.

Druhý sjezd na ochranu památek $v$ Praze 1913 (IV. sjezd archeologů a spolků muzejních). Praha 1915.

GUTH, Karel (G). Fejeton (musea). Národní listy, 10. V. 1913, s. 1.

GUTH, Karel. K programu činnosti českých muzeí. Časopis společnosti přátel starožitností českých, 1913, roč. 21, č. 2, s. 93.

HARLAS, František Xaver. Svaz československých museí vlastivědných. Časopis Společnosti prátel starožitností českých, 1920, č. 1, roč. 28, s. 46-49.

HOFFMANOVÁ, Jaroslava. Václav Novotný (1869-1932). Život a dílo univerzitního profesora českých dějin. Praha: Academia, 2014. ISBN 978-80-200-2341-4.

JANEČKOVÁ, Jitka. Mráz kopřivu nespálí. Život a dílo Fridolína Macháčka a Václava Vojtíška ve vzájemné korespondenci z let 1905-1954. Praha: Scriptorium, 2014. ISBN 978-80-88013-01-3.

JENÍČEK, Václav Vladislav. O organisaci musejních spolků českoslovanských. Časopis Společnosti přátel starožitností českých, 1898, roč. 6, č. 3, s. 133-134. MACHÁČEK, Fridolín. Kazimourův podíl na vývoji českého musejnictví. Časopis pro dějiny venkova, 1933, roč. 20, č. 3. s. 158-161.

NIEDERLE, Lubomír. Několik slov o pěstování české archeologie. Český lid, 1892, roč. 1, s. 317-331.

PALÁRIK, Miroslav. Museums in the Slovak Republic (1939-1945) - origins, visions and reality. Museologica Brunensia, 2017, roč. 6, č. 2, s. 46-55. ISSN 1805-4722. https://doi.org/10.5817/MuB2017-2-4

PAKOSTA, Ferdinand. Dodatek k článku o Svazu musejí. Časopis společnosti prátel starožitností českých, 1910, roč. 18, č. 2, s. 60 .

Rozhledy po musejní práci v Československu. Časopis pro dějiny venkova, 1931, roč. 18, č. 3. s. 271; 1932, roč. 19 , č. 2 , s. 140 , č. 3. s. 225.

Sjezd českých archeologů a spolků musejních konaný 27. a 28. srpna 1898 na Horách Kutných. Praha: Společnost přátel starožitností českých, 1898.

Sjezd českých archeologů a spolků musejních konaný 27. srpna 1898 na Horách Kutných. Časopis společnosti prátel starožitností českých, 1898, roč. 6, č. 3, s. 110-136.

Sjezd na ochranu památek v Praze ve dnech 27.-28. září 1908. Časopis společnosti přátel starožitností českých, 1908, roč. 16, č. 4, s. 211-212.

Sjezd na ochranu památek 27.-28. září 1908 v Praze. Českoslovanské letopisy musejní, 1910, roč. 2, $144 \mathrm{~s}$.

Svaz vlastivědných muzeí československých. Časopis společnosti prátel starožitností českých, 1919, roč. 27, č. 1, s. 69-71.

SKLENÁŘ, Karel. Obraz vlasti. Př́běh Národního muzea. Praha: Paseka, 2001. ISBN 80-7185-399-2.

STOCKÝ, Albín. Svaz museí a musejních spolků. Časopis společnosti prátel starožitností českých, 1910, roč. 18, č. 2, s. 56-59.

STOCKÝ, Albín. K článku o Svazu musejí. Časopis společnosti prátel starožitností českých, 1910, roč. 18, č. 2, s. 60.

ŠEBEK, František. Architektura muzejních budov, funkční členění a vybavení prostor. In BURIÁNKOVÁ, Michaela, Anna KOMÁRKOVÁ a František
ŠEBEK (eds.). Úvod do muzejní praxe. Praha: Asociace muzeí a galerií České republiky, 2010, s. 371-374.

ISBN 978-80-86611-40-2.

ŠEBEK, František. Sít a struktura muzeí. In ŠEBEK, František a kol. (eds.). Muzea ČR $v$ letech 2012-2014 ve světle statistiky. Praha: NIPOS, 2015, s. 11-12. ISBN 978-80-7068-300-2.

ŠEBEK, František. Stav muzejnictví z pohledu statistických dat. In BENČOVÁ, Monika a Anna KOMÁRKOVÁ (eds.). Muzeum a změna V./The Museum and Change V.: Sborník z mezinárodní muzeologické konference $v$ Národním archivu v Praze 22.-24. listopadu 2016. Praha: Asociace muzeí a galerií České republiky, 2017, s. 135-137. ISBN 978-80-86611-77-8.

ŠEBEK, František. Role Svazu československých muzeí ve vývoji českého (československého) muzejnictví. In HUPKO, Daniel a Luděk BENEŠ (eds.). Dokumentácia „osmičkových“ výročí v slovenských a českých múzeách. Rok 1918 a tie ostatné. Banská Bystrica: Zväz múzeí na Slovensku, 2018,

s. $128-142$.

ISBN 978-80-971748-7-3.

ŠPÉT, Jiří. Vznik Svazu československých muzeí. Muzejní a vlastivědná práce, 1971, roč. 9, č. 2, s. 90-109.

ŠPÉT, Jiří. Muzea ve vývoji společnosti a národní kultury. Praha: Národní muzeum, 1979.

ŠPÉT, Jiří. Přehled vývoje českého muzejnictví I. (do roku 1945). 2. vyd. Brno: Masarykova univerzita v Brně, 2003. ISBN 80-210-32-06-5.

ŠTEFÁNEK, Antonín. PhDr. Josef Kazimour jako musejník. Časopis pro dějiny venkova, 1933, roč. 20, č. 3. s. 154-158.

WIRTH, Zdeněk. Organizace ministerstva školství a národní osvěty Československé republiky. Umění, 1918, roč. 1, s. 246-249.

ŽALUD, Augustin. Česká kulturní politika a musea. In TOBOLKA, Zdeněk (ed.). Politika. Co má věděti o Československé republice každý občan. Praha, 1925, díl II/3, s. 182-189. 


\section{FRANTIŠEK ŠEBEK}

Ústav historických věd, Fakulta filozofická, Univerzita Pardubice, Česká republika

frsebek@seznam.cz

Od roku 1968 do 2009 pracoval ve Východočeském muzeu v Pardubicích nejprve jako historik a správce numismatické sbírky, později jako vedoucí historického oddělení, náměstek ředitele a posledních 19 let (1991 až 2009) jako ředitel muzea. V letech 1991 až 2000 byl předsedou Asociace muzeí a galerií ČR. Poté zde působil ještě několik let jako člen exekutivy, dosud je zde i lektorem a vedoucím Školy muzejní propedeutiky, členem pracovní skupiny pro muzejní statistiku ad. Současně od roku 2000 dosud přednáší na Ústavu historických věd Fakulty filozofické Univerzity Pardubice, kde mimo jiné přednáší úvod do muzeologie. Odborně se zaměřuje na historii (regionální dějiny, pozdní středověk a raný novověk), v muzeologii zvláště na muzejní výstavnictví, muzejní statistiku, management a marketing). Externě působí na Filozofické fakultě Masarykovy univerzity v Brně.

From 1968 until 2009 he has worked in the East Bohemian Museum in Pardubice, initially as a historian and curator of the numismatic collection, later as the head of the historical department, deputy director and in the last 19 years (1991 to 2009) as the museum director. From 1991 until 2000 he was president of the Czech Association of Museums and Galleries. Thereafter he has been active there for several years as an Executive Board member, now he continues as a lecturer and head of the School of Museum Propaedeutics, member of a working group for museum statistics, etc. Since 2000 to this day he also gives lectures, among others also the Introduction to Museology, in the Department of Historical Sciences at the Faculty of Arts, University of Pardubice. His professional interest is focused on history (regional history, Late Middle Ages and Early Modern Era) and museology (particularly museum exhibitions, museum statistics, management and marketing). He is external teacher at the Faculty of Arts of the Masaryk University in Brno. 